\title{
Death Diagnosis Sequence Number
}

National Cancer Institute

\section{Source}

National Cancer Institute. Death Diagnosis Sequence Number. NCI Thesaurus. Code

C117543.

An identifier that describes the relative position of death diagnoses data within a series. 